\title{
Pelaksanaan Zakat Susu Perah di Desa Bendosari Kecamatan Sanan Kulon Kabupaten Blitar Ditinjau dari Fikih Zakat Yusuf Qardlawi
}

\author{
Supriyanto, Ratna Tri Lestari \\ Institut Agama Islam Nahdlatul Ulama Tuban, UIN Maulana Malik Ibrahim \\ Malang \\ E-mail: supriyanto.aqil@gmail.com, ratna.elthree@gmail.com
}

\begin{abstract}
Abstrak: Zakat mal merupakan zakat yang digunakan untuk membersihkan harta dari kotoran. Zakat mal terdiri dari dua macam, yaitu zakat mal klasik yang telah dijelaskan dalam nash dan zakat mal modern/kontemporer yang tidak dijelaskan dalam nash. Salah satu contohnya adalah zakat produksi peternakan sapi perah. Pada masa sekarang zakat produksi peternakan sapi perah masih awam di kalangan masyarakat. Mereka beranggapan bahwa hasil produksi peternakan sapi perah tidak wajib dikeluarkan zakatnya. Padahal jika dilihat dari 'illat hukumnya, zakat produksi peternakan sapi perah bisa berkembang secara kuantitas serta dapat menghasilkan keuntungan. Oleh karena itu, hasil produksi peternakan sapi perah harus dikeluarkan zakatnya, seperti zakat susu. Penelitian ini menggunakan observasi lapangan dan wawancara langsung dengan para informan yang berkaitan dengan bidang kajian. Adapun literatur dan dokumentasi yang didapatkan mengenai persoalan yang terkait digunakan sebagai sumber data sekunder. Penelitian ini menyimpulkan bahwa masyarakat Desa Bendosari telah melaksanakan zakat susu sapi perah sebagaimana yang telah disyari'atkan oleh agama. Akan tetapi dalam pelaksanaannya mereka menganalogikan zakat susu sapi perah dengan zakat perdagangan, sehingga pelaksanaan zakat susu sapi perah yang mereka laksanakan tidak sesuai dengan Fiqh zakat Yusuf Qardlawi karena Yusuf Qardlawi beranggapan bahwa susu harus diperlakukan sama dengan madu, sehingga zakatnya dianalogikan dengan zakat pertanian.

Kata Kunci: Zakat susu, hukum Islam, fiqh Yusuf Qardlawi.
\end{abstract}

\section{Pendahuluan}

Dalam ajaran agama Islam, waktu yang tersedia hendaknya diisi dengan kegiatan melaksanakan ibadah kepada Allah dan kegiatan mencari rezeki, sebagai karunia dari Allah Yang Maha Pengasih dan 
Penyayang. Orang yang tidak mengisi waktu kegiatan itu, berarti orang itu telah menyia-nyiakan kesempatan yang berharga. Mengabaikan salah satu saja, sudah dianggap rugi, apalagi meninggalkan kedua-duanya. Sebenarnya mencari rezeki itu, tidak perlu ada anjuran atau paksaan dari orang lain. Kesadaran kerja harus timbul dari dalam diri setiap manusia. Oleh karena itu, setiap orang mempunyai kewajiban mencari rezeki untuk memenuhi kepentingan mereka masing-masing.

Perintah mencari rezeki atau harta (menjadi orang kaya) telah diperintahkan dalam al-Quran, walaupun tidak secara langsung. Umpamanya, perintah berzakat (muzakkiy) dan berinfak. Bagaimana mungkin orang berzakat dan berinfak, tanpa ada harta kekayaan. Hal ini berarti, supaya setiap muslim berusaha menjadi hartawan. Andai kata belum mungkin berzakat, tetapi sekurang-kurangnya dapat berinfak. ${ }^{1}$

Zakat merupakan suatu kewajiban yang harus dilaksanakan oleh setiap umat Islam. Dalam Islam zakat merupakan salah satu cara yang dapat digunakan untuk menyucikan diri atau harta. Oleh karena itu, setiap umat muslim diwajibkan mengeluarkan zakat guna menyucikan jiwa dan hartanya. Zakat selama ini hanya diasumsikan kepada zakat fitrah dan lima jenis zakat yang sudah umum dibincang dalam kitab-kitab fikih klasik. Kelima sumber zakat itu adalah zakat emas perak, pertanian, peternakan, perdagangan, dan barang temuan. Padahal banyak sumbersumber penghasilan yang kini justru lebih besar hasilnya daripada kelima golongan tersebut. ${ }^{2}$ Sehingga dengan mengeluarkan zakat dari harta yang dimiliki dapat menjadikan harta itu bersih.

Dengan demikian dalam hal ini terdapat permasalahan, bahwa kelima jenis sumber zakat di atas atau yang sudah dikenal dengan zakat mal tidak hanya sekedar dari lima hal tersebut, akan tetapi segala sesuatu yang dijadikan penghasilan atau penghidupan juga harus dizakati. Zakat mal yang seperti ini kemudian disebut sebagai zakat mal modern atau zakat mal kontemporer.

Mengenai kewajiban mengeluarkan zakat mal modern/kontemporer menurut Yusuf Qardlawi terdapat beberapa syarat yang harus dipenuhi, yaitu: ${ }^{3}$

\footnotetext{
${ }^{1}$ M. Ali Hasan, Zakat dan Infak, (Jakarta: Kencana, 2008), hlm.11

2 Sudirman, Zakat Dalam Pasaran Arus Modernitas, (Malang: UIN Malang Press, 2007), hlm. 57-59.

3 Yusuf Qardlawi, Hukum Zakat, Terj. Salman Harun, Didin Hafidhuddin dan Hasanuddin, (Jakarta: Litera Antar Nusa, t.t.), hlm. 125-161
} 
1. Milik penuh.

2. Al-Namâ' (berkembang secara kuantitas).

3. Cukup senishab.

4. Lebih dari kebutuhan biasa.

5. Berlaku satu tahun.

Di era globalisasi ini, manusia telah berhasil mengembangkan segala potensinya, baik eksternal maupun internal dirinya. Yang termasuk konsep eksternal adalah manusia mampu mengeksploitasi antara lain laut, tanah, gedung, surat-surat berharga, dan kendaraan-kendaraan. Sedangkan yang tergolong potensi dalam dirinya adalah kemampuan manusia mengembangkan keahlian untuk mendapat keuntungan yang besar, misal profesi dosen, dokter, dan advokat. Konsep pertumbuhan dan perkembangan kekayaan manusia dapat juga dicermati dalam berbagai kegiatan budidaya hewan dan tumbuhan. Berbagai macam kekayaan alam yang ada dapat dikembangkan melalui proses budidaya yang merupakan suatu proses penerapan sains khususnya bioteknologi. 4 Salah satunya peternakan sapi perah yang dapat dibudidayakan untuk menghasilkan susu.

Pada masa sekarang zakat produksi peternakan sapi perah masih awam di kalangan masyarakat. Hal ini terjadi karena kekurang pahaman mereka mengenai zakat. Mereka beranggapan bahwa hasil produksi peternakan sapi perah itu tidak ada zakatnya. Padahal jika dilihat dari 'illat hukumnya zakat produksi peternakan sapi perah bisa berkembang secara kuantitas serta dapat menghasilkan keuntungan. Zakat produksi peternakan sapi perah yang dimaksud adalah berupa susu. Dalam hal ini, ada satu daerah yang terkenal dengan sapi perah, yakni desa Bendosari. Desa ini terdapat sekitar 150 lebih sapi yang menjadi sumber penghasilan masyarakat, salah satunya adalah $H$. Panggih. Ia mempunyai sebanyak 52 ekor sapi perah. Ia juga sudah melaksanakan zakat. Namun, masih banyak peternak yang masih belum paham tentang zakat dan tidak berzakat.

Permasalahan inilah yang menjadi sorotan utama penulis untuk melakukan penelitian. Dalam penelitian ini penulis akan menguraikan tentang pelaksanaan zakat susu sapi perah ditinjau dari Fikih zakat Yusuf Qardlawi yang dilakukan oleh masyarakat desa Bendosari sudah sesuai dengan syari'at Islam atau belum. Hal ini dikarenakan Fikih Zakat Yusuf

${ }^{4}$ Sudirman, Zakat Dalam Pasaran Arus Modernitas, hlm. 63 
Qardlawi lebih banyak dikenal dibandingkan dengan kitab-kitab fikih zakat kontemporer lainnya. Dengan adanya penelitian ini penulis bisa meluruskan praktik pelaksanaan zakat produksi hewan kepada masyarakat setempat sesuai dengan pengetahuan penulis. Untuk itu, penelitian ini merupakan penelitian yang menarik untuk dilakukan. Sebab, praktek zakat kontemporer yang dilakukan masyarakat masih perlu disesuaikan dengan kitab Fikih zakat yang telah ada, yang salah satunya adalah Fikih zakat Yusuf Qardlawi.

Yusuf Qardlawi dalam kitabnya Figh Zakat berpendapat bahwa produk-produk hewani seperti susu dan sebagainya, harus diperlakukan sama dengan madu, yang oleh karena itu dipungut zakatnya sebesar sepersepuluh dari penghasilan bersih (berlaku pada ternak-ternak piaraan yang khusus diambil susunya dan tidak merupakan barang dagangan). ${ }^{5}$

\section{Pengertian Zakat}

Ditinjau dari segi bahasa, kata zakat berasal dari kata dasar (masdar)

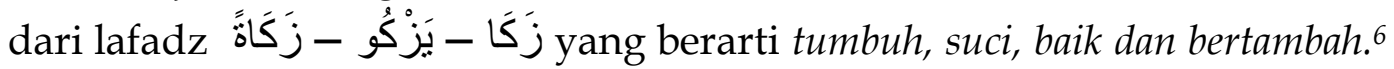
Sedangkan menurut istilah zakat merupakan ukuran yang telah ditentukan dari harta wajib zakat yang disalurkan kepada delapan golongan penerima zakat dengan syarat-syarat tertentu. ${ }^{7}$

Menurut istilah para ulama ahli Fiqh, zakat adalah menyerahkan harta secara putus yang telah ditentukan oleh syariat kepada orang-orang yang berhak menerimanya. Ada yang berpendapat, zakat adalah hak Allah Subhanahu Wa Ta'âlâ yang harus dipenuhi terhadap harta tertentu. ${ }^{16}$

Kata zakat dalam bentuk ma'rifah (definisi) disebut tiga puluh kali di dalam al-Quran, di antaranya dua puluh tujuh kali disebutkan dalam satu ayat bersama shalat, dan hanya satu kali disebutkan dalam konteks yang sama dengan shalat tetapi tidak dalam satu ayat, ${ }^{17}$ yaitu dalam firman-Nya QS. al-Mu'minuun (23): 4.

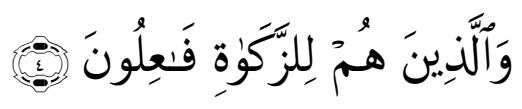

Artinya: "Dan orang-orang yang menunaikan zakat" 8

Bila diperiksa ketiga puluh kali zakat disebutkan itu, delapan terdapat

\footnotetext{
${ }^{5}$ Yusuf Qardlawi, Hukum Zakat, hlm. 405

${ }^{6}$ Muhammad Yunus, Kamus Bahasa Arab Indonesia (Jakarta: PT. Mahmud Yunus Wa Dzurriyyah,2007), hlm. 156

7 Fakhruddin al-Muhsin, Ensiklopedi Mini Zakat, Terj. Agus Abu Aufia. (Bogor: Darul Ilmi,2011), hlm. 7

${ }^{8}$ Q.S. al-Mukminun:4
} 
di dalam surat-surat yang turun di Makkah dan selebihnya di dalam surat-surat yang turundi Madinah. ${ }^{19}$

\section{Hukum Zakat}

Zakat adalah rukun ketiga dari rukun Islam yang lima. Zakat hukumnya wajib atas setiap muslim, berdasarkan dalil-dalil berikut ini: 25

1. Dalil al-Qur'an, yaitu firman Allah QS. al-Bayyinah (98): 5.

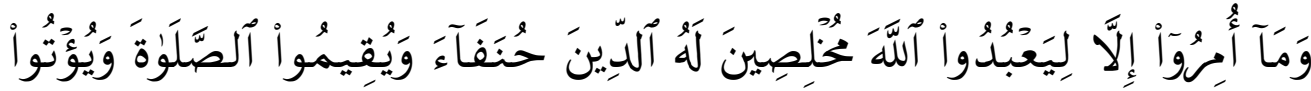

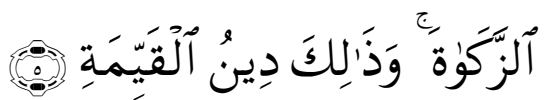

Artinya: Padahal mereka tidak disuruh kecuali supaya menyembah Allah dengan memurnikan ketaatan kepada-Nya dalam (menjalankan) agama yang lurus, dan supaya mereka mendirikan shalat dan menunaikan zakat; dan yang demikian Itulah agama yang lurus. ${ }^{9}$

2. Dalil dari Sunnah Rasulullah, yaitu hadits Ibnu Umar r.a.

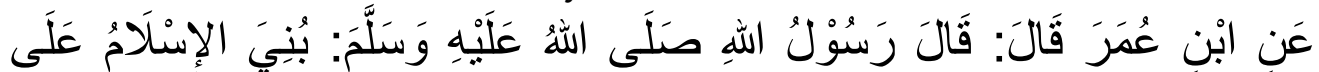

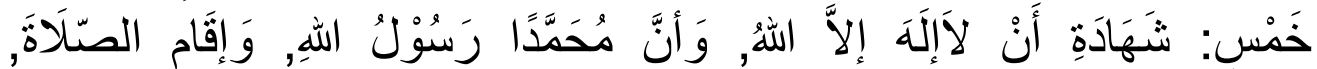

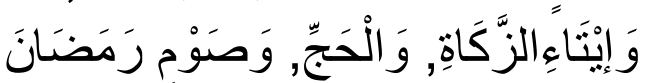

Artinya: Ibnu Umar berkata, "Rasulullah saw bersabda, 'Islam itu dibangun atas lima dasar: 1) bersaksi bahwa tidak ada Tuhan yang berhak diibadahi kecuali Allah, dan bahwa Nabi Muhammad adalah Utusan Allah; 2) menegakkan shalat; 3) membayar zakat; 4) haji; 5) puasa pada bulan Ramadhan.'"10

Dari hadis di atas dapat difahami bahwa tiang agama itu ada lima, yaitu syahâdatain, mendirikan shalat, menunaikan zakat, melaksanakan haji dan puasa pada bulan Ramadhan. Jika salah satu dari tiang agama itu tidak dilaksanakan maka iman seseorang itu masih belum sempurna. Jadi ketika seseorang tidak mau melaksanakan zakat atas dirinya atau hartanya maka imannya masih belum sempurna dan ia akan mendapatkan siksa. Karena zakat merupakan rukun Islam yang ketiga, sehingga zakat itu hukumnya wajib untuk dilaksanakan.

Seluruh umat Islam sepakat bahwa zakat itu hukmnya wajib. Kewajiban zakat sudah diketahui dari agama secara pasti bagi orang-

${ }^{9}$ Q.S. al-Bayyinah:5

${ }^{10}$ M. Nashiruddin al-Albani, Ringkasan Shahih Bukhari, Terj. As'ad Yasin dan Elly Latifa, (Jakarta: Gema Insani,2003), hlm. 24 
orang yang hidup di tengah-tengah kaum muslimin dan di masyarakat yang islami. Barangsiapa di antara mereka yang mengingkarinya, ia adalah kafir dan dianggap sebagai orang yang murtad atau keluar dari agama Islam. Ia disuruh bertaubat sebanyak tiga kali. Jika masih tidak mau bertaubat, maka sanksi baginya dalah seperti sanksi bagi orang yang keluar dari agama dan mengkufurinya, yaitu dibunuh. Adapun bagi orang yang mengingkari kewajiban zakat karena ia memang tidak tahu, maka ia tidak bisa dihukumi kafir karena alasan-alasan tersebut. Ia harus diajari, diperkenalkan, dan disebutkan dalil-dalilnya. ${ }^{28}$

\section{Syarat Wajib Zakat}

Syarat seseorang wajib mengeluarkan zakat adalah sebagai berikut:

a. Islam

b. Merdeka

c. Berakal dan baligh

d. Memiliki nishab

Adapun syarat-syarat nishab adalah sebagai berikut:

1. Harta tersebut di luar kebutuhan yang harus dipenuhi seseorang, seperti makanan, pakaian, tempat tinggal, kendaraan, dan alat yang dipergunakan untuk mata pencaharian.

2. Harta yang akan dizakati telah berjalan selama satu tahun (haul) terhitung dari hari kepemilikan nishab dengan dalil hadits Rasulullah saw. ${ }^{11}$

\section{Pengertian Zakat Mal}

Menurut bahasa, kata mal berarti kecenderungan, atau segala sesuatu yang diinginkan sekali oleh manusia untuk dimiliki dan disimpannya. Sedangkan menurut syara', mal adalah segala sesuatu yang dapat dimiliki atau dikuasai dan dapat digunakan (dimanfaatkan) sebagaimana lazimnya.

Dengan demikian, sesuatu dapat disebut mal apabila memenuhi dua syarat berikut:

1) Dapat dimiliki, disimpan, dihimpun, dikuasai.

2) Dapat diambil manfaatnya sesuai dengan lazimnya. Contohnya rumah, mobil, ternak, hasil pertanian, uang, emas, perak, dan lain sebagainya. Sedangkan sesuatu yang tidak dapat dimiliki tetapi manfaatnya dapat diambil, seperti udara dan sinar matahari tidaklah disebut mal.

${ }^{11}$ Fakhruddin al-Muhsin, 16-20 
Syarat Harta Yang Wajib Dizakati

a) Kepemilikan sempurna

b) Berkembang (produktif atau berpotensi produktif)

c) Mencapai nishab

d) Melebihi kebutuhan pokok

e) Terbebas dari hutang

f) Kepemilikan satu tahun penuh $($ al-Haul $){ }^{12}$

\section{Sumber Zakat Konvensional}

Terdapat beberapa pendapat ulama' tentang macam harta yang wajib dikeluarkan zakatnya, di antaranya adalah sebagaimana dirangkum Fakhruddin:

1. Abdurrahman al-Jaziri mengatakan bahwa harta yang wajib dikeluarkanzakatnya ada lima macam, yaitu hewan ternak (unta, sapi dan kambing), emas dan perak, barang dagangan, barang tambang dan rikâz (barang temuan), serta tanam-tanaman dan buah-buahan.

2. Sayyid Sabiq mengatakan bahwa harta yang wajib dikeluarkan zakatnya adalah emas, perak, hasil tanaman, buah-buahan, barangbarang perdagangan, binatang ternak, barang tambang dan barang temuan (harta karun).

3. Ibnul Qayyim al-Jauziyah dalam kitabnya Zad al-Ma'ad mengatakan bahwa harta yang menjadi sumber zakat yang dikemukakan secara terperinci dalamal-Quran dan hadits ada 4 (empat) jenis, yaitu tanamtanaman dan buah- buahan, hewan ternak, emas dan perak serta harta perdagangan.

4. Wahbah al-Zuhaili mengatakan bahwa harta yang wajib dizakati ada 5 (lima), yaitu nuqûd (emas, perak dan surat-surat berharga), barang tambang dan barang temuan, barang perdagangan, tanam-tanaman dan buah-buahan, dan hewan ternak (unta, sapi dan kambing). Wahbah juga mengutip pendapat Abu Hanifah yang mewajibkan kuda juga wajib dizakati.

5. Hasbi al-Shiddiqy membagi harta yang wajib dizakati dibagi menjadi dua, yaitu harta-harta zhahir (al-amwâl al-zhahîriyyah), yaitu binatang, tumbuh- tumbuhan dan buah-buahan, dan harta-harta yang tersembunyi (al-amwâl al-bathîniyyah), yaitu emas, perak dan barang

12 Lembaga Amil Zakat, "Fiqh Zakat", http://zakat.or.id/bab-ii-zakat-mal-harta/, diakses pada tanggal 5 Desember 2013 
perniagaan.

6. Ibnu Rusyd membagi harta yang wajib dikeluarkan zakatnya menjadi dua, yaitu, pertamayang disepakati dua macam dari barang tambang (emas dan perak), tiga macam dari hewan (unta, sapi dan kambing), dua macam dari biji-bijian (gandum dan syâ'ir), dua macam dari buahbuahan (kurma dan kismis). Kedua, yang diperselisihkan, yaitu emas yang dibuat menjadi pakaian. ${ }^{13}$

\section{Zakat Properti Produktif}

Properti produktif adalah aset properti yang diproduktifkan untuk meraih keuntungan atau peningkatan nilai materiil dari properti tersebut. Properti tersebut tidak diperjualbelikan dan tidak pula dikhususkan untuk memenuhi kebutuhan primer individu. Produktivitas properti diusahakan dengan cara menyewakannya kepada orang lain atau denga jalan menjual hasil dari produktifitasnya.

Syarat-syarat aset yang tergolong dalam kategori wajib zakat properti produktif adalah sebagai berikut:

1. Properti tersebut tidak dikhususkan untuk komoditas perdagangan.

2. Properti tidak dikhususkan untuk pemenuhan kebutuhan primer bagi pemiliknya, seperti tempat tinggal dan sarana transportasi untuk mencari rezeki.

3. Properti yang disewakan atau dikembangkan untuk tujuan mendapatkanpenghasilan baik sifatnya rutin atau tidak rutin. ${ }^{14}$

Dari persyaratan di atas, berikut beberapa contoh aset properti produktif wajib zakat:

a. Rumah sewaan

b. Usaha angkutan transportasi

c. Proyek pengembangbiakan hewan pedaging

d. Proyek hasil budi daya hewan ternak

e. Perusahaan penghasil madu

\section{Nishab Zakat Properti Produktif}

Mayorias ahli Fiqh berpendapat bahwa nishab zakat properti produktif dianalogikan dengan nishab komoditas perdagangan dan aset keuangan yaitu sepadan dengan nilai 85 gram emas atau 200 dirham perak. Penghitungan tersebut didasarkan atas prinsip haul yaitu

\footnotetext{
${ }^{13}$ Fahruddin, Figh dan Manajemen Zakat di Indonesia, (Malang: UIN Press, 2008), hlm. 89-90

14 Lembaga Amil Zakat, "Fiqh Zakat", http://zakat.or.id/bab-ii-zakat-mal-harta/, diakses pada tanggal 5 Desember 2013
} 
dijumlahkan seluruh pendapatan periodik- bulanan ataupun tidak-selama satu tahun. Jika kemudian jumlah total pendapatan tersebut melebihi nishab, maka wajib dizakatkan. Mayoritas ahli Fiqh tersebut menyandarkan pendapatnya pada Imam bin Hambal dalam zakat pertanian dan perkebunan yang menyatukan seluruh pendapatan bulanan selama satu tahun. Beliau berkata, “... Apabila masa panen madu lebah dalam setahun dua kali, makagabungkanlah keduanya."15

Dalam hal ini yang menjadi objek zakat yang dikeluarkan zakatnya, hanyalah komoditas perdagangannya saja, seperti susu dan sutera saja. Sedangkan sarana dan prasarananya, seperti pabrik dan sarananya tidaklah wajib dikeluarkan zakatnya. ${ }^{16}$

\section{Persentase Volume Zakat Properti Produktif}

Ahli Fiqh modern berpendapat bahwa kadar dari zakat properti produktif di- qiyas-kan dengan zakat pertanian dan perkebunan tadah hujan yaitu $10 \%$ dari hasil bersih (net income).

Sauqi Sahatah berpendapat bahwa penentuan volume zakat properti produktif memerlukan kajian-kajian dan riset yang mendalam, beliau berpandangan bahwa kadar kewajiban zakat properti produktif berkisar antara $5 \%$ dan $7.5 \%$ dari total hasil (brutto revenue) dan bukan dari net revenue. Sebab, bentuk-bentuk beban biaya yang harus dikurangi dari pendapatan tersebut membutuhkan suatu kajian dan analisis yang lebih mendalam dan sangat dimungkinkan untuk menjadi bahan perdebatan. ${ }^{17}$

\section{Kalkulasi Sumber Zakat Properti Produktif}

Penghitungan zakat properti produktif secara garis besar adalah sebagaiberikut:

1. Penentuan total pendapatan satu tahun yang disesuaikan dengan harga pasar di akhir tahun.

2. Penentuan biaya langsung dan tidak langsung begitu pula dengan biaya- biaya lain yang terkait selama satu tahun dan keterkaitan tersebut merupakan kausalitas antara unsur-unsur biaya dan pendapatan.

3. Menentukan penyusutan aktiva tetap selama satu tahun yang dihitung berdasarkan biaya pengganti (replacement cost).

4. Pendapatan dikurangi biaya langsung dan tidak langsung serta

\footnotetext{
${ }^{15}$ M. Arief Mufraini, Akuntasi dan Manajemen Zakat, (Jakarta: Kencana, 2006) hlm. 93-95

${ }^{16}$ Fahruddin, hlm. 70

${ }^{17}$ M. Arief Mufraini, hlm. 96
} 
jumlah penyusutan untuk menentukan pendapatan bersih (net income).

5. Pendapatan dikurangi hutang dan kebutuhan pokok.

6. Zakat properti produktif dihitung berdasarkan $10 \%$ dari pendapatan bersih jika telah mencapai nishab. ${ }^{18}$

\section{Landasan Hukum Zakat Produk Ternak}

Pada zaman sekarang dikenal ternak bukan gembala yang diambil susunya dan memberikan penghasilan yang besar kepada pemiliknya. Produksi belum dikenal oleh orang-orang Muslim pada zaman Nabi, zaman sahabat, dan zaman sesudah mereka, sehingga mereka belum menetapkan hukumnya. ${ }^{19}$

Mengenai zakat produksi hewani seperti sutera dan susu, sebagian ulama' seperti Imam Malik, Syafi'i, Ibnu Abi Laila, Hasan bin Shalih dan Ibnu Mundziri menyatakan bukan sebagai sumber zakat sehingga tidak wajib dikeluarkan. ${ }^{20}$ Tetapi sebagian lagi menyatakan sebagai sumber zakat, sehingga wajib dikeluarkan, apabila telah memenuhi persyaratan sebagai sumber zakat. Disamping terjadi perbedaan pendapat dalam menentukan statusnya, perbedaan pendapat pun terjadi dalam analogi kewajiban zakatnya, apakah pada hasil pertanian ataukah pada perdagangan. ${ }^{21}$

\section{Nishab Zakat Produk Hewani}

Produk-produk hewani jelas sekarang ini termasuk ke dalam sumber zakat, bahkan juga menjadi komoditas perdagangan. Tumbuh dan berkembangnya pabrik susu dan pabrik sutera sekarang ini membuktikan kenyataan tersebut. Atas dasar itu pula, penganalogian objek zakat tersebut pada zakat perdagangan, di samping pendapat yang menganalogikannya kepada pertanian. Kalau analognya kepada perdagangan, maka nishab-nya senilai dengan 85 gram emas, dan wajib dikeluarkan zakatnya setiap tahun sebesar $2.5 \%$.

Namun jika dianalogikan kepada pertanian, maka nishab-nya adalah senilai $653 \mathrm{~kg}$ padi/gabah atau gandum dan persentase zakatnya sebesar $10 \%$ dikeluarkan pada setiap panen. ${ }^{22}$ Hal ini karena zakat sapi perah

\footnotetext{
${ }^{18}$ M. Arief Mufraini, hlm. 98-99

${ }^{19}$ Qardlawi, hlm 405

20 Johani, Zakat 'Asl (Madu Lebah) Dalam Prespektif Yusuf al-Qardlawi, Skripsi Fakultas Syari'ah, (Semarang: IAIN Walisongo Semarang, 2005), hlm. 36

${ }^{21}$ Fahruddin, hlm. 169-170

22 Fahruddin, hlm. 170
} 
disamakan dengan zakat pertanian dengan tadah hujan, sehingga persentase zakatnya adalah $10 \%$ bukan $5 \%$.

\section{Fiqh Zakat Yusuf Qardlawi Tentang Zakat Produk Hewani}

a) Latar Belakang Pemikiran Yusuf Qardlawi

Yusuf Qardlawi termasuk salah satu ulama terkenal yang sangat produktif dalam menulis buku. Tidak kurang dari 125 buku telah ditulisnya dan sebagian telah diterjemahkan ke dalam berbagai bahasa di dunia, termasuk bahasa Indonesia. Pemikirannya yang tertuang dalam berbagai tulisan dan ceramah telah berkontribusi banyak dalam pergerakan Islam kontemporer sekaligus mengilhami kebangkitan Islam modern.

Kapasitas keilmuan Yusuf Qardlawi tidak lepas dari latar belakang pendidikan dan keluarganya. Ia dilahirkan tahun 1926 di Desa Shaft Turab, Provinsi Manovia Mesir dari sebuah keluarga yang sederhana akan tetapi kuat kultur keagamaannya. Yusuf Qardlawi dikenal sebagai ulama dan pemikir Islam yang unik dan istimewa. Ia memiliki cara atau metodologi khas dalam menyampaikan risâlah Islam yang cenderung moderat. Dasar utama moderasi, khususnya moderasi Fiqh dari Qardlawi adalah al-Qur'an dan hadits. Dengan metodologi yang diusungnya ini, ulama kelahiran Mesir ini mudah diterima di kalangan dunia barat sebagai seorang pemikir yang selalu menampilkan Islam secara ramah, santun, dan moderat. ${ }^{23}$

Banyak orang yang mengenal Yusuf Qardlawi dengan pemikiran Islamnya yang cemerlang dari kemajuan pendidikan Islam, orangorang bisa mengenal Pemikiran Salafinya. Yang dimaksud dengan "Pemikiran Salafi" ialah kerangka berpikir (manhaj fikri) yang tercermin dalam pemahaman generasi terbaik dari umat ini.

Kriteria Manhaj Salafi yang benar adalah suatu manhaj yang secara global berpijak pada prinsip berikut:

1. Berpegang pada nash-nash yang $m a^{\prime}$ shûm (suci), bukan kepada pendapat para ahli atau tokoh

2. Mengembalikan masalah-masalah "mutasyâbihat" (yang kurang jelas) kepada masalah "muhkamât" (yang pasti dan tegas), serta mengembalikan masalah yang zhanni kepada yang qath'iy

3. Memahami kasus-kasus fur $\hat{u}^{\prime}$ (kecil) dan juz'iy (tidak

${ }^{23}$ Islamobile, "Yusuf al-Qardlawi", http://Islamobile.net/?p=85, diakses pada tanggal 22 Maret 2014 
prinsipil), dalam kerangka prinsip dan masalah fundamental

4. Menyerukan "Ijtihâd" dan pembaharuan. Memerangi "Taqlîd"dan kejumudan

5. Mengajak untuk ber-iltizam (memegang teguh) akhlak Islamiah, bukan meniru trend

6. Dalam masalah Fiqh, berorientasi pada "kemudahan" bukan "mempersulit"

7. Dalam hal bimbingan dan penyuluhan, lebih memberikan motivasi, bukan menakut-nakuti

8. Dalam bidang akidah, lebih menekankan penanaman keyakinan, bukan dengan perdebatan

9. Dalam masalah ibadah, lebih mementingkan jiwa ibadah, bukan formalitasnya

10. Menekankan sikap "ittibâ"' (mengikuti) dalam masalah agama dan menanamkan semangat "ikhtirâ"' (kreatifitas dan daya cipta) dalam masalahkehidupan duniawi. ${ }^{24}$

Dalam bidang Fiqh, Qardlawi telah berhasil membuat sebuah formulasi dalam pemberlakuan Fiqh, terutama ketika dalam menghadapi persoalan- persoalan kontemporer. Di antara formula yang dibangunnya adalah mengenai perlunya dibangun sebuah Fiqh baru (figh jadîd) antara lain: Fiqh al-Muwâzanah (Fiqh keseimbangan), Fiqh Waqi'iy (Fiqh realitas), Fiqh al-Aulâwiyyât (Fiqh Prioritas), Fiqh alMaqâshid al-Syarî́ah, dan Figh al-Taghyîr (Fiqh Perubahan).

Selain itu, kontribusi yang diberikan Qardlawi dalam bidang Fiqh adalah bagaimana mencairkan kebekuan dan kejumudan umat Islam dalam menghadapi perubahan zaman. Menurutnya, salah satu penyebab kejumudan tersebut adalah berhentinya kreatifitas umat dalam berijtihad yang merupakan dapur utama bagi kemajuan mereka. ${ }^{25}$

b) Pemikiran Yusuf Qardlawi tentang Zakat Produk Hewani

Ulama-ulama Fiqh mengemukakan tentang alasan tidak wajibnya zakat atas susu ternak gembalaan dan alasan wajibnya atas zakat

\footnotetext{
24 Siti Maesaroh, "Makalah alQardlawi",http://www.academia.edu/3614949/MAKALAH_YUSUF_ALQARDAWI,diakses pada tanggal 22 Maret 2014.

${ }^{25}$ Suhartono, "YUSUF QARDLAWI: (Percikan Pemikiran Fiqh dan Metode Ijtihadnya)", http//artikelfakta.blogspot.com/2013/07/yusuf-qardlawi-percikan-pemikiran-

Fiqh.html, diakses pada tanggal 22 Maret 2014
} 
madu, sedangkan keduanya sama produksi hewani. Para ulama Fiqh memang membedakan antara susu ternak gembalaan dari madu lebah; susu ternak gembalaan yang dasarnya, yaitu ternak gembalaan itu, sudah dikeluarkan zakatnya, yang oleh karena itu tidak sama dengan madu. Hal itu berarti bahwa sesuatu yang dasarnya belum dikeluarkan zakatnya wajib dikeluarkan zakatnya dari produksinya. Dalam hal ini susu sapi dan produk hewani sejenisnya dapat diqiyaskan dengan madu lebah, karena kedua-duanya produk hewani yang belum dikeluarkan zakatnya dari dasarnya. ${ }^{26}$

Ketentuan yang bisa ditegaskan di sini adalah bahwa dasar yang belum dikeluarkan zakatnya wajib dikeluarkan zakatnya dari produksinya, seperti hasil tanaman dari tanah, madu dari lebah, susu dari binatang ternak, telur dari ayam, dan sutera dari ular sutera. Hal ini adalah pendapat dari Imam Yahya, salah seorang fuqaha Syi'ah, yang mewajibkan sutera dikeluarkan zakatnya, seperti zakat madu karena kedua-duanya keluar dari pohon. ${ }^{27}$

Di antara ulama Fiqh dari mazhab Zaidiah seperti Hadi, Muayyid Billah dan lain-lainnya berpendapat lain tentang hewan ternak yang dimaksudkan untuk investasi dan penambahan penghasilan. Mereka menggolongkannya harta dagangan yang oleh karena itu wajib dihitung nilai antara modal dan keuntungannya, lalu wajib dikeluarkan zakatnya $2.5 \%$ dari modal dan keuntungan tersebut. Ini menurut segolongan ulam Fiqh mazhab Zaidiah seperti Hadi, Muayyid Billah dan lain-lainnya.

Seseorang yang membeli kuda untuk dijual produknya misalnya atau sapi untuk dijual susunya, atau ulat sutera untuk dijual suteranya, atau sejenisnya, maka orang itu harus menghitung nilai benda-benda tersebut bersama dengan produknya pada akhir tahun, lalu mengeluarkan zakatnya sebesar zakat perdagangan.

Hal itu tidak hanya berlaku pada hewan-hewan produksi saja, tetapi juga meliputi seluruh harta benda yang diinvestasi di luar sektor perdagangan, seperti rumah-rumah yang disewakan atau lainlainnya. Sekarang cukup dikatakan bahwa pengiasan produk-produk hewani dengan madu adalah benar dan tidak ada alasan untuk menolaknya.

${ }^{26}$ Yusuf Qardlawi, hlm. 405

27 Yusuf Qardlawi 405-406 
Oleh karena itu, Yusuf Qardlawi dalam kitabnya Figh Zakat berpendapat bahwa produk-produk hewani seperti susu dan sebagainya, harus diperlakukan sama dengan madu, yang oleh karena itu dipungut zakatnya sebesar sepersepuluh dari penghasilan bersih (berlaku pada ternak-ternak piaraan yang khusus diambil susunya dan tidak merupakan barang dagangan). ${ }^{28}$

\section{Metode Pengumpulan Data}

Dalam melakukan suatu penelitian para peneliti memerlukan metodemetode tertentu untuk dapat mengumpulkan data. Metode-metode tertentu seperti yang telah dikenal selama ini yaitu berupa studi kepustakaan/studi dokumen (documentary study), wawancara (interview), daftar pertanyaan (kuesioner), dan pengamatan (observasi). ${ }^{29}$

Berkaitan dengan pernyataan di atas, pengumpulan data dalam metode penelitian ini hanya menggunakan metode studi kepustakaan/studi dokumen (documentary study), wawancara (interview) dan pengamatan (observasi). Karena penelitian ini menggunakan penelitian kualitatif bukan kuantitatif. Oleh karena itu, metode daftar pertanyaan tidak diperlukan dalam pengumpulan data.

Metode-metode tersebut akan penulis uraikan sebagai berikut:

1. Studi Kepustakaan/Studi Dokumen (Documentary Study)

Studi dokumen dalam penelitian ini merupakan dokumen cetak (hard copy). Dokumen cetak ini antara lain adalah data manajemen pengeluaran dan pemasukan produksi hewan serta data-data mengenai hasil dari penjualan produksi hewan tersebut. Data-data tersebut dapat dijadikan penulis sebagai bahan untuk mengumpulkan data yang sesuai dengan isu hukum yang diangkat oleh penulis.

2. Wawancara (Interview)

Metode wawancara yang digunakan adalah wawancara secara langsung dan mendalam yang dilakukan dengan cara tanya jawab secara langsung di manasemua pertanyaan disusun secara sistematik, jelas dan terarah sesuai dengan isu hukum yang diangkat dalam penelitian. ${ }^{62}$ Dalam wawancara, penulis merupakan instrument paling utama, karena penulis menyampaikan pertanyaan yang tidak terstruktur. Wawancara ini dilakukan dengan pihak yang

\footnotetext{
28 Yusuf Qardlawi, hlm. 405-406

29 Bambang Wahyu, Penelitian Hukum Dalam Praktek, (Jakarta: Sinar Grafika, 2008), hlm. 18-19
} 
bersangkutan dengan permasalahan ini, yaitu para peternak sapi perah yang ada di Desa Bendosari Kecamatan Sanan Kulon Kabupaten Blitar, di ataranya adalah Abdul Kalim, Kasirin, Sugito, Paelan, Ismadi dan H. Panggih Suparngadi. Selain itu juga wawancara dilakukan dengan petugas KUD di Desa tersebut dimana hasil produksi hewan tersebut disetorkan, sehingga dengan wawancara tersebut penulis dapat mengumpulkan data- data yang berhubungan dengan hasil penjualan produksi hewan tersebut.

3. Pengamatan (Observasi)

Selain menggunakan metode wawancara dan dokumentasi, penulis juga menggunakan metode observasi. Karena permasalahan ini membutuhkan penelitian serta penyelidikan dan juga menguji hipotesis dengan cara mempelajari dan memahami mengenai gejalagejala apa saja yang terjadi di masyarakat sehingga dapat mengakibatkan adanya suatu permasalahan di dalamnya. Dengan adanya metode observasi ini penulis dapat mengetahui gejala-gejala apa saja yang terdapat di masyarakat, sehingga penulis dapat melakukan penelitian mengenai gejala-gejala tersebut.

\section{Pelaksanaan Zakat}

Fakta yang terjadi di Desa Bendosari Kecamatan Sanan Kulon Kabupaten Blitar menegaskan bahwa masyarakat yang berprofesi sebagai peternak sapi perah mempunyai kewajiban untuk mengeluarkan zakat hasil dari susu perahan ternaknya jika telah mencapai nishab yang ditentukan, karena zakat produk hewani berupa susu dapat dianalogikan pada zakat perdagangan, sehingga prosentase zakatnya adalah sebesar $2.5 \%$ dari hasil bersih yang dikeluarkan setiap akhir tahun. ${ }^{30}$

Sebagaimana pendapat segolongan ulama Fiqh mazhab Zaidiah seperti Hadawiyah, Muayyid Billah dan lain-lainnya bahwa hasil produksi hewani termasuk komoditas perdagangan yang diperjualbelikan. Maka sebaiknya menggunakan nishab seperti halnya zakat perdagangan, yaitu sebesar 85 gram emas dan apabila diuangkan sebesar Rp. 42.500.000,- dengan besar zakat sebanyak 2.5\% dari hasil susu.

Memang terdapat perbedaan pendapat dalam menentukan kadar zakat yang harus dikeluarkan untuk zakat produk hewani. Dalam pelaksanaannya masyarakat bisa memilih salah satu dari penganalogian

30 Yusuf Qardlawi, hlm. 406 
zakat susu baik dengan zakat pertanian maupun dengan zakat perdagangan. Akan tetapi masyarakat Desa Bendosari lebih memilih menganalogikannya dengan zakat perdagangan, karena pemahaman mereka bahwa hasil susu yang harus dizakati adalah hasil dari penjualan susu itu sendiri, sehingga jika dizakati juga mengikuti zakat perdagangan.

Jika demikian, sebagaimana yang telah dipaparkan oleh Abdul Kalim, Sugito dan Ismadi yang rata-rata memiliki ternak berkisar antara 10 - 14 ekor sapi perah, yang mana tidak semuanya dapat berproduksi. Maka dapat diambil kesimpulan bahwa jika setiap tahunnya mereka ratarata mengeluarkan biaya makan sebanyak Rp. 30.000.000,- per tahun dan kesehatan sebesar Rp. 936.000,- per tahun. Adapun penghasilan yang didapatkan per tahun adalah sebesar Rp. 72.900.000,--

Jika dikalkulasikan:

\begin{tabular}{|l|l|l|l|}
\hline \multirow{2}{*}{ Hasil Kotor } & \multicolumn{2}{|c|}{ Pengeluaran } & \multirow{2}{*}{ Jumlah Akhir } \\
\cline { 2 - 3 } & Makan & Kesehatan & \\
\hline Rp.72.900.000 & Rp.30.000.000 & Rp.939.000 & \multirow{2}{*}{ Rp. 41.964.000 } \\
\hline
\end{tabular}

Dilihat dari tabel di atas hasil bersih per tahun bisa mencapai Rp. 41.964.000,-. Jika nishab-nya sebesar 85 gr emas, maka 85 x Rp. 500.000,(hargaper gram emas) $=$ Rp. 42.500.000,-, maka mereka belum mempunyai kewajiban untuk mengeluarkan zakat karena masih belum mencapai nishab.

Kemudian, sebagaimana yang dipaparkan oleh Paelan. Jika sapi perah yang dimiliki sebanyak 20 ekor sapi perah dan yang berproduksi hanya 12 ekor sapi perah maka, untuk biaya makan 20 ekor sapi Paelan dapat mengeluarkan biaya sebanyak Rp. 144.000.000,- per tahun dan untuk biaya kesehatan bisa mencapai Rp. 960.000,- per tahun. Adapun sapi yang berproduksi hanya 12 ekor yang per tahunnya bisa menghasilkan sebanyak Rp. 194. 400.000,--

Untuk mengetahui kewajiban mengeluarkan zakat, dapat dikalkulasikan:

\begin{tabular}{|l|l|l|l|}
\hline \multirow{2}{*}{ Hasil Kotor } & \multicolumn{2}{|c|}{ Pengeluaran } & \multirow{2}{*}{ Jumlah Akhir } \\
\cline { 2 - 3 } & Makan & Kesehatan & \\
\hline Rp. 194.400.000 & Rp. 144.000.000 & Rp. 960.000 & Rp. 49.440.000 \\
\hline
\end{tabular}


Dari tabel di atas dapat diketahui penghasilan bersih Paelan setiap tahunnya mencapai Rp. 49.440.000,-. Jadi, sebenarnya ia telah wajib mengeluarkan zakat karena hasil susu ternak yang dimilikinya telah mencapai nishab, sedangkan nishab untuk zakat produksi hewani sebesar Rp. 42.500.000,-.

Kemudian untuk ternak yang dimiliki oleh H. Panggih Suparngadi. Apabila penghasilan per harinya mencapai 300 liter atau Rp. 1.350.000,-, maka penghasilan per tahun yang didapat oleh $\mathrm{H}$. Panggih mencapai Rp. 486.000.000,-. Untuk biaya pangan ternak H. Panggih setiap tahunnya mengeluarkan biaya sebesar Rp. 187.200.000,- dan untuk biaya pekerja setiap tahun ia mengeluarkan biaya sebesar Rp. 84.240.000,-.

\begin{tabular}{|l|l|l|l|}
\hline \multirow{2}{*}{ Hasil Kotor } & \multicolumn{2}{|c|}{ Pengeluaran } & \multirow{2}{*}{ Jumlah Akhir } \\
\cline { 2 - 3 } & Makan & Gaji Pegawai & \\
\hline Rp. 486.000.000 & Rp.187.200.000 & Rp. 84.240.000 & Rp. 216.560.000 \\
\hline
\end{tabular}

Jadi penghasilan bersih $\mathrm{H}$. Panggih per tahun adalah sebesar Rp. 216.560.000,-. Kemudian dari hasil bersih yang didapat, H. Panggih mengambil $2.5 \%$ untuk dikeluarkan zakatnya karena ternak susu sapi perah yang ia jalankan telah mencapai nishab wajib mengeluarkan zakat, sehingga zakat yang ia keluarkan per tahun sebesar Rp. $216.560 .000 \times 2.5 \%$ $=$ Rp. 5.414.000,-. Zakat tersebut ia serahkan ke madrasah, pondok atau masjid yang terletak di daerah pemukimannya.

Hal ini sesuai dengan perintah Allah terhadap umat Islam untuk membayar zakat agar harta yang dimilikinya menjadi bersih dan suci. Karena kalau tidak dibayarkan zakatnya, harta yang dimiliki menjadi kotor dan haram karena tercampur hak orang lain yang dititipkan kepada orang yang berhak mengeluarkanzakat. ${ }^{31}$

Allah berfirman dalam QS. al-Zariyat (51) ayat 19:

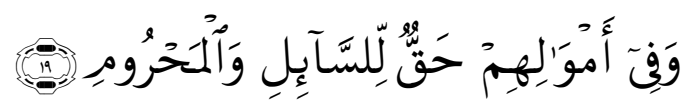

Artinya: dan pada harta-harta mereka ada hak untuk orang miskin yang meminta dan orang miskin yang tidak mendapat bagian. ${ }^{32}$

Dari ayat di atas dapat diketahui bahwa hukum zakat itu wajib,

31 Arif Hidayat, " Pengertian, Jenis dan Golongan Penerima Zakat serta Ruang Lingkupnya", http://basicartikel.blogspot.com/2013/pengertian-jenis-dan golonganpenerima_24.html, diakses pada tanggal 2 Desember 2014

32 Q.S. al_Zariyat: 19 
sehingga setiap orang yang mempunyai harta yang telah mencapai nishab harus menyisakan $2.5 \%$ dari hartanya untuk dikeluarkan zakatnya, sehingga harta yang mereka miliki menjadi suci dan bersih. Seperti halnya yang telah dilaksanakan oleh para peternak di Desa Bendosari.

Data-data di atas telah sesuai dengan pelaksanaan zakat properti produktif. Mayoritas ahli Fiqh berpendapat bahwa nishab zakat properti produktif dianalogikan dengan nishab komoditas perdagangan dan aset keuangan, yaitu sepadan dengan nilai 85 gram emas atau 200 dirham perak. Penghitungan tersebut didasarkan atas prinsip haul yaitu dijumlahkan seluruh pendapatan periodik- bulanan ataupun tidak-selama satu tahun. Jika kemudian jumlah total pendapatan tersebut melebihi nishab, maka wajib dizakatkan. ${ }^{33}$ Dalam hal ini yang menjadi objek zakat yang dikeluarkan zakatnya, hanyalah komoditas perdagangannya saja, seperti susu dan sutera, sedangkan sarana dan prasarananya, seperti pabrik dan sarananya tidaklah wajib dikeluarkan zakatnya. ${ }^{34}$

Hal ini telah sesuai dengan pelaksanaan zakat yang dilaksanakan oleh Kasirin dan H. Panggih Suparngadi. Mereka telah mengumpulkan hasil dari ternak sapi perah yang dimiliki selama satu tahun untuk dikeluarkan zakatnya. Adapun sarana prasarana yang mereka miliki tidak dimasukkan dalam penghitungan zakat.

\section{Zakat Susu Sapi Perah Ditinjau dari Fiqh Zakat Yusuf Qardlawi}

Pada bab sebelumnya penulis telah menjelaskan berbagai hal mengenaizakat produksi hewani dan pendapat dari beberapa ulama Fiqh mengenai zakat produksi hewani. Sebagaimana dalam kitab Figh al-Zakat karya Yusuf Qardlawi dijelaskan bahwa sesuatu yang dasarnya belum dikeluarkan zakatnya wajib dikeluarkan zakatnya dari produksinya. Dalam hal ini susu sapi dan produk hewani sejenisnya dapat diqiyaskan dengan madu lebah, karena kedua-duanya termasuk produk hewani yang belum dikeluarkan zakatnya dari dasarnya.

Qardlawi berpendapat bahwa produk-produk hewani seperti susu dan sebagainya harus diperlakukan sama dengan madu, yang oleh karena itu diambil zakatnya sebesar sepersepuluh atau 10\% dari penghasilan bersih (hal ini berlaku pada ternak-ternak piaraan yang khusus diambil susunya dan tidak merupakan barang dagangan) ${ }^{78}$ dengan nishab sebesar lima wasaq (653 Kg gabah kering atau lima puluh kail Mesir) karena

\footnotetext{
${ }^{33}$ M. Arief Mufraini, hlm. 95

${ }^{34}$ Fahruddin, hlm. 170
} 
dianalogikan dengan zakat pertanian.

Makanan pokok masyarakat Indonesia adalah beras, sehingga zakatnya harus memenuhi nishab sebesar $653 \mathrm{~kg}$ gabah kering. Adapun harga gabah kering per $\mathrm{kg}$ adalah Rp. 4500,-. Jadi, nishab-nya adalah sebagai berikut:

\begin{tabular}{|c|c|c|c|c|}
\hline Nishab & $\begin{array}{c}\text { Harga } \\
\text { Per Kg }\end{array}$ & $\begin{array}{c}\text { Kewajiban } \\
\text { Mengeluarkan Zakat }\end{array}$ & Persentase & $\begin{array}{c}\text { Zakat Yang } \\
\text { Dikeluarkan }\end{array}$ \\
\hline 653Kg & Rp. 4500,- & Rp. 2.938.500,- & $10 \%$ & Rp. 293.850,- \\
\hline
\end{tabular}

Ketika hasil produk hewani berupa susu sudah mencapai Rp. 2.938.500,-, maka hasil susu tersebut wajib dizakati sebesar Rp. 293.850,yang harus dikeluarkan setiap kali panen.

Dari paparan di atas, sebagaimana yang telah dijelaskan Yusuf Qardlawi dalam kitabnya yang berjudul Figh al-Zakat, jika zakat susu diqiyaskan dengan zakat madu, maka Abdul Kalim, Sugito, Ismadi, Paelan, Kasirin dan H. Panggih Suparngadi mempunyai kewajiban mengeluarkan zakat karena hasil susu yang mereka dapatkan telah memenuhi nishab yang telah ditentukan.

Sebagaimana pendapat Yusuf Qardlawi yang menyatakan bahwa zakat produk hewani baik yang berupa susu maupun produk lainnya harus disamakan seperti halnya zakat madu, maka zakat susu sapi perah ini prosentasenya adalah $10 \%$ dari hasil susu yang dikeluarkan setiap kali panen. Sehingga dari pelaksanaan zakat yang dilakukan oleh peternak di Desa Bendosari sebagaimana yang telah penulis uraikan pada sub bab sebelumnya tidak sesuai atau masih kurang tepat dengan pelaksanaan zakat sebagaimana tertera di dalam kitab Figh al-Zakat milik Yusuf Qardlawi yang menetapkan bahwa persentase zakat susu adalah 10\% dari hasil susu yang didapat setiap kali panen.

Dalam pelaksanaannya, Kasirin dan H. Panggih Suparngadi mengeluarkan zakat sebesar $2.5 \%$ dari pendapatan bersih hasil susu sapi perah yang mereka keluarkan setiap tahun sekali. Ini tidak sesuai dengan pendapat Yusuf Qardlawi dalam kitabnya Figh al-Zakat yang menyatakan bahwa zakat dari hasil susu sapi perah yang dikeluarkan haruslah sebesar 10\% dari hasil susu yang dikeluarkan setiap kali panen.

Hal ini dikarenakan para peternak masyarakat Desa Bendosari dalam melaksanakan zakat tidak mengacu pada Figh al-Zakat buah karya Yusuf 
Qardlawi yang sampai sekarang karyanya sangat terkenal di kalangan masyarakat. Akan tetapi, mereka lebih cenderung pada pendapat segolongan ulama Fiqh mazhab Zaidiah seperti Hadawiyah, Muayyid Billah dan lain-lainnya yang menyatakan bahwa hasil produksi hewani termasuk komoditas perdagangan karena diperjualbelikan, sehingga zakat produk hewani berupa susu dianalogikan dengan zakat perdagangan. Dalam pelaksanaannya, mereka menerapkan sebagaimana pendapat yang mereka ikuti, yaitu dengan menganalogikannya dengan zakat perdagangan bukan dengan zakat pertanian sebagaimana dijelaskan dalam kitab figh al-Zakat buah karya Yusuf al-Qardlawi.

Dari data-data yang penulis paparkan di atas, dapat diambil kesimpulan bahwa para peternak sapi perah di Desa Bendosari dalam pelaksanaannya tidak sesuai dengan pelaksanaan zakat yang terdapat dalam kitab fiqh zakat Yusuf Qardlawi karena mereka lebih memilih mengikuti pendapat ulama lain yang menyatakan bahwa susu merupakan komoditas perdagangan yang diperjualbelikan.

\section{Penutup}

Pelaksanaan zakat susu di Desa Bendosari hanya dilakukan oleh mereka yang hasil ternaknya telah mencapai nishab dan para peternak besar atau yang biasa masyarakat sana sebut dengan "juragan sapi perah". Biasanya mereka menyisakan 2.5\% dari hasil susu untuk dizakatkan sebagaimana yang telah disyari'atkan oleh agama. Zakat-zakat yang mereka keluarkan itu terkadang mereka berikan kepada masyarakat sekitar, madrasah, pondok atau masjid di sekitar kawasan pemukiman mereka. Penyaluran zakat susu sapi perah ini mereka salurkan sendiri secara langsug tanpa melalui Badan Amil Zakat (BAZ).

Menurut Yusuf Qardlawi zakat susu sapi perah merupakan bentuk zakatkontemporer yang wajib dikeluarkan zakatnya. Adapun zakat yang harus dikeluarkan yaitu sebesar $10 \%$ dari jumlah susu yang diperoleh yang dikeluarkan setiap kali panen. Hal ini dikarenakan zakat susu dianalogikan dengan zakat pertanian, sehingga prosentase zakatnya disamakan dengan zakat pertanian. Akan tetapi, masyarakat di Desa Bendosari dalam kebiasaannya mengeluarkan zakat hasil susu sebesar $2.5 \%$. Menurut mereka zakat susu dianalogikan dengan zakat perdagangan sehingga dilaksanakan setiap tahun sekali. Oleh karena itu, pelaksanaan zakat susu yang dilakukan oleh peternak di Desa Bendosari masih belum sesuai dengan pelaksanaan zakat sebagaimana dijelaskan 
oleh Yusuf Qardlawi dalam kitabnya Figh Zakat karena dalam keseharian mereka tidak menggunakan pendapat Yusuf Qardlawi sebagai landasan dalam mengeluarkan zakat.

\section{Daftar Pustaka}

Bambang Wahyu. Penelitian Hukum Dalam Praktek. Jakarta: Sinar Grafika, 2008.

Fahruddin. Figh dan Manajemen Zakat di Indonesia. Malang: UIN Press, 2008.

Fakhruddin al-Muhsin. Ensiklopedi Mini Zakat. Terj. Agus Abu Aufia. Bogor: Darul Ilmi,2011.

M. Ali Hasan. Zakat dan Infak. Jakarta: Kencana, 2008.

M. Arief Mufraini. Akuntasi dan Manajemen Zakat. Jakarta: Kencana, 2006.

M. Nashiruddin al-Albani. Ringkasan Shahih Bukhari. Terj. As'ad Yasin dan Elly Latifa. Jakarta: Gema Insani,2003.

Muhammad Yunus. Kamus Bahasa Arab Indonesia. Jakarta: PT. Mahmud Yunus Wa Dzurriyyah,2007.

Sudirman. Zakat Dalam Pasaran Arus Modernitas. Malang: UIN Malang Press, 2007.

Yusuf Qardlawi. Hukum Zakat. Terj. Salman Harun, Didin Hafidhuddin dan Hasanuddin. Jakarta: Litera Antar Nusa, t.t.

Johani. Zakat 'Asl (Madu Lebah) Dalam Prespektif Yusuf al-Qardlawi, Skripsi Fakultas Syari'ah, Semarang: IAIN Walisongo Semarang, 2005.

Lembaga Amil Zakat, "Fiqh Zakat”, http://zakat.or.id/bab-ii-zakat-malharta/

Islamobile, "Yusuf al-Qardlawi", http:/ / Islamobile.net/?p=85

Siti "Maesaroh, "Makalah Yusuf al-Qardlawi", http://www.academia.edu/3614949/MAKALAH_YUSUF_ALQARDAWI

Suhartono, “YUSUF QARDLAWI: (Percikan Pemikiran Fiqh dan Metode Ijtihadnya)", $\quad$ http//artikelfakta.blogspot.com/2013/07/yusufqardlawi-percikan-pemikiran-Fiqh.html

Hidayat, Arif. “ Pengertian, Jenis dan Golongan Penerima Zakat serta RuangLingkupnya",http:/ / basicartikel.blogspot.com/2013/pengertia n-jenis-dan golongan-penerima_24.html. 
The Indonesian Journal of Islamic Law and Civil Law Vol. 2, No. I, April, 2021, ISSN. xxxx - xxxx 